\title{
EU Law and the EEAS: Of Complex Competences and Constitutional Consequences
}

\author{
Geert De Baere and Ramses A. Wessel ${ }^{1}$
}

To be published in J. Bátora and D. Spence (Eds.), The EU's Diplomatic System: postWestphalia and the European External Action Service, Basingstoke: Palgrave MacMillan, 2014 (forthcoming)

\section{Introduction}

In her foreword to the 2013 EEAS Review, High Representative for the Union's Foreign and Security Policy (HR) Baroness Ashton likened the early days of the EEAS and its setting-up phase to 'trying to fly a plane while still bolting the wings on' (EEAS Review 2013: 1). This chapter explores the nuts and bolts of the construction of the EEAS. An astonishing amount of law is involved. While foreign policy and law have forever been strange bedfellows (De Baere 2012: 359-360; Wessel 2014), European integration is essentially a project of legalization (Cappelletti, Seccombe, and Weiler 1986). The EU is a system constructed on the basis of law. It has even created its own distinctive legal system, and its everyday functions are dominated by legal niceties and practical legal implications (Allott 1999: 37 and 46; De Baere 2012: 364). Law also played a determining role in the fraught negotiation process setting up the EEAS (Erkelens and Blockmans 2012; Van Vooren 2011), and it continues to have a crucial impact on its daily functioning. At the same time, the EEAS is a groundbreaking legal construction, and as such it has had an impact on EU constitutional law ${ }^{1}$, which it has influenced and even transformed.

The main goal of this chapter is to explore the basic legal framework applicable to the EEAS and to examine the impact of the EEAS on the constitutional law of the EU. It addresses the division of competences between the Union and the Member States and explores the impact of the EEAS on the EU as a constitutional entity. The chapter illustrates the legal intricacies involved in the basic framework within which the EEAS functions. It points to some of the constitutional consequences, yet with no pretence of exhaustiveness. Finally, the chapter focuses on the internal EU rules and constitutional consequences. As such it is the counterpart of chapter X, by Wouters and Duquet, which studies the international legal context within which the EEAS is constrained to operate.

\footnotetext{
1 Respectively Assistant Professor of EU Law and International Law at the Faculty of Law and Senior Member of the Leuven Centre for Global Governance Studies, University of Leuven, Belgium; and Professor of International and European Institutional Law, Centre for European Studies, University of Twente, The Netherlands.
} 


\section{The Legal Framework of the EEAS}

It is useful to recall the general legal framework for EU external representation within which the EEAS operates. Before the entry into force of the Lisbon Treaty, the Commission represented EU positions concerning the (Maastricht) first pillar, while the Council Presidency represented the Union in other cases, mostly pertaining to the common foreign and security policy (CFSP). However, the Lisbon Treaty removed all explicit references in the Treaties to the role of the Council Presidency in the external representation of the Union. The new Treaty rules (Articles 17 and 27(2) TEU) set a clear framework: the High Representative ensures the external representation of the EU for the CFSP, and the Commission is the EU representative for other external relations matters. In sum, Article 17 TEU provides that, with the exception of the CFSP and other cases provided for in the Treaties, the Commission is to ensure the Union's external representation. In the CFSP, external representation is ensured by the High Representative (Article 18(2) TEU) and 'at his level and in that capacity' by the President of the European Council, without prejudice to the powers of the High Representative (Article 15(6) TEU).

In fulfilling his mandate, the High Representative is assisted by the EEAS, which is to 'work in cooperation with the diplomatic services of the Member States and shall comprise officials from relevant departments of the General Secretariat of the Council and of the Commission as well as staff seconded from national diplomatic services of the Member States. The organisation and functioning of the European External Action Service shall be established by a decision of the Council. The Council shall act on a proposal from the High Representative after consulting the European Parliament and after obtaining the consent of the Commission' (Article 27(3) TEU). In sum, all we know of the EEAS after reading the EU Treaty is its name, the basic outline of its function and composition, and by what procedure it is to be established. The EEAS was established by a Council decision as a 'functionally autonomous body' of the EU, 'separate from the General Secretariat of the Council and from the Commission' 2 and 'with the legal capacity necessary to perform its tasks and attain its objectives' (Art 1(2) EEAS Decision). Yet, it is not listed in Article 13 TEU and is therefore not an institution. ${ }^{3}$ This indeterminate status is the result of a compromise between those seeking the EEAS to be an essentially intergovernmental body close to or part of the Council and those preferring it to be close to or part of the Commission. The EEAS was thus set up as a 'sui generis' body 'equidistant' from the Council and the Commission (Van Vooren 2011: 501). Significantly, a study commissioned by the European Parliament found that most stakeholders now agree that the sui generis positioning of the EEAS was a mistake: the Commission perceives the construction of the EEAS as a loss of power that ought to be regained or protected, while Member States believe the priorities set out by the EEAS often compete with their own national priorities (Wouters et al. 2013). The fact that the EEAS is not an institution proper therefore makes it significantly more difficult for it fully to perform its tasks. It lacks the capacity for legal enforcement of the EU common interest in external relations, and more generally, it does not have a final say over most of the EU's external relations tools. The EEAS can hence not fully and faithfully support the mandate of the High 
Representative in attaining coherent EU external action as this would require less fragmentation of the policies and competences over different actors (Wouters et al. 2013: 20).

The inherent structural complexities of the EEAS are evident from the enumeration of its tasks in the Decision establishing the service. First, the EEAS is to "support the High Representative in fulfilling his/her mandates' (Art 2(1) EEAS Decision), the enumeration of which reflects Articles 18 and 27 TEU and includes conducting the CFSP and common security and defence policy (CSDP) (Art 18(2) TEU), ensuring the consistency of the EU's external action (Art 18(4) TEU), presiding over the Foreign Affairs Council (Art 18(3) TEU), and acting as Vice-President of the Commission. This latter capacity not only includes 'responsibilities incumbent on [the Commission] in external relations' but also 'coordinating other aspects of the Union's external action' (Art 18(4) TEU). Second, the EEAS must 'assist the President of the European Council, the President of the Commission, and the Commission in the exercise of their respective functions in the area of external relations' (Art 2(2) EEAS Decision). The 2013 EEAS Review noted that in 2012 the EEAS had in fact prepared more than twice the number of briefings for the President and other members of the Commission as it had for the High Representative herself (EEAS Review 2013: 8). Third, the EEAS is to 'support, and work in cooperation with, the diplomatic services of the Member States as well as the General Secretariat of the Council and the services of the Commission, in order to ensure consistency between the different areas of the Union's external action and between those areas and its other policies' (Art 3(1) EEAS Decision and Art 21(3), second para., TEU). Fourth, the EEAS must 'extend appropriate support and cooperation to the other institutions and bodies of the Union, in particular to the European Parliament' (Art 3(4) EEAS Decision). With the exception of the CFSP/CSDP, this complex set of tasks is determined by reference to other EU external actors, which includes a fragile balancing act vis-à-vis ('without prejudice to the normal tasks of') the General Secretariat of the Council and the services of the Commission. While this definition assumes the existence of a common understanding of what 'normal tasks' entail, it is quite clear that the establishment of the EEAS has created a 'new normal', which appears to have as a consequence the predominant focus of the High Representative and the EEAS on its CFSP (and CSDP) tasks (Blockmans and Hillion 2013: 20-21), leaving the Commission to remain in control of most of the TFEU external policies (i.e. the former first pillar). The set-up of the EEAS, supporting the High Representative in conducting the CFSP and ensuring coherence in EU external action, has also led the Commission to run a parallel structure in external relations covering policies that fall within the Commission's purview (Wouters et al. 2013: 46-49). Furthermore, while Article 2 EEAS Decision is entitled 'Tasks', it does not contain an exhaustive or even comprehensive description of what those tasks encompass. Regard must additionally be had to other provisions of the EEAS Decision, such as Articles 4 on the Central administration of the EEAS and 5 on Union delegations, as well as to other tasks entrusted to the EEAS in a more ad hoc manner by, for example, the European Council (Blockmans and Hillion 2013: 24-26). The open-ended and convoluted manner in which the EEAS' mandate is defined has had an inevitably detrimental impact on the functioning of the EEAS (Wouters et al. 2013: 25).

The complexity of the legal framework is not helped by the fact that Article 3 of the EEAS Decision contains a list of broad cooperative duties (Wouters et al. 2013: 18-19). First, 
the EEAS must work in cooperation with Member State diplomatic services. Second, the EEAS and the services of the Commission are to "consult each other on all matters relating to the external action of the Union in the exercise of their respective functions, except on matters covered by CSDP', and the EEAS is to 'take part in the preparatory work and procedures relating to acts to be prepared by the Commission in this area' (Art 3(2) EEAS Decision). No similar explicit obligation vis-à-vis the Council is provided for, though some degree of mutual consultation must follow from the general duty of sincere cooperation in Article 4(3) TEU. Nevertheless, while the list of cooperative duties may complicate the balancing act to be performed by the EEAS, they are also inevitable for the 'bridge' function between the various aspects of EU external relations the EEAS is supposed to perform (Blockmans and Hillion 2013: 28 and 32; Bátora 2013). They also reflect the obligation for the Union to ensure consistency between the various areas of its external action and between these and its other policies. This obligation is to be ensured by the Council and the Commission, assisted by the High Representative, who are to cooperate to that effect (Article 21(3) TEU). Such consistency can only be achieved through sincere cooperation between all the actors involved: the several EU institutions and bodies that operate in the area of EU external action as well as the Member States, as mandated not only by Article 3 EEAS Decision, but also by Articles 4(3) and 13(2) TEU.

The entry into force of the Lisbon Treaty also saw the replacement of the Commission delegations by Union delegations, which act as the Union's diplomatic representations and are as such part of the EEAS (Wessel 2013). Pursuant to Article 221 TFEU, Union delegations in third countries and at international organisations are to represent the Union. They are to be placed under the authority of the High Representative and to act in close cooperation with Member States' diplomatic and consular missions. The Lisbon Treaty attributed the important competence for deciding on the opening or closing of a delegation to the High Representative, who does so in agreement with the Council and the Commission (Art 5(1) EEAS Decision). The Head of Delegation is a de facto EU ambassador (Wouters and Duquet 2012: 31-49). He or she receives instructions from the High Representative and the EEAS and is responsible for their execution. However, the Commission can also issue instructions to delegations in areas that fall within its sphere of competence. Such instructions are then to be executed under the overall responsibility of the Head of Delegation (Art 5(3) EEAS Decision). In order to forestall contradictory instructions, recital 13 in the preamble to the EEAS Decision provides for the Commission and the EEAS to agree on detailed arrangements relating to the issuing of instructions from the Commission to the delegations. These should provide in particular that when the Commission issues instructions to delegations, it will simultaneously provide a copy to the Head of Delegation and to the EEAS central administration (European Commission Secretariat General 2012).

The 2013 EEAS Review notes that arrangements are working well, but adds that further strengthening of the division for Development Cooperation coordination, for example through the secondment of more national experts, would help to raise the profile and impact of the EEAS in this area (EEAS Review 2013: 9). The involvement of the EEAS in development cooperation and its relationship with the Commission's DG DEVCO have in fact not been an unqualified success (Wouters et al. 2013: 50-51). Thus, useful though the arrangements may be, they also provide a clear illustration of the challenges facing two 
separate actors with a significant role in the external representation of the Union in coordinating policy and avoiding unseemly contradictions (Wessel and Van Vooren 2013: 8). For example, it has been reported that instructions from the Commission tend to disregard local political considerations and priorities set by the EEAS (Wouters et al. 2013: 66-67). A distinction nonetheless needs to be made between bilateral settings on the one hand, where the transition from Commission to Union delegations is reported to have gone relatively smoothly, and multilateral delegations on the other hand (See the chapters on bilateral and multilateral delegations). As the EEAS Review acknowledges: 'The situation has been more complicated in multilateral delegations (New York, Geneva, Vienna, Paris, Rome, Strasbourg) given the complexity of legal and competence issues and the very heavy workload associated with EU co-ordination meetings' (EEAS Review 2013: 10-11). The issues pertain in particular to the complexity of the vertical (between the Union and the Member States) and horizontal (between the different Union institutions and policies) division of competences within the EU. The issues are reviewed in the next section, where the varying status of the EU in other international organisations is also discussed (Wouters et al. 2013: 77). The EEAS Review concluded that while the general principle that both the EEAS and the Commission may send instructions to Heads of Delegation, with a copy to the responsible EEAS geographical desks, works well in practice, the coordination of human resources management remains based on two separate structures, and this leads to multiple debates on the same issues and consequent delays in decision-making. The potential confusion, not to mention turf battles, also create an obstacle to direct contact between the EEAS and Commission services with policy stakes defended and represented by Delegations (EEAS Review 2013: 11 and House of Lords European Union Committee 2013: 22-23, para 51).

Perhaps surprisingly, given the objective of a single diplomatic representation, the EU Special Representatives (EUSRs) (Art 33 TEU) are neither mentioned in Article 5 EEAS Decision, nor indeed anywhere else in the decision. As Hanses points out in chapter X, the EUSRs disappeared in practice after Lisbon, a fact reflected in the EEAS Review, which refers to the current status of EUSRs unambiguously as 'an anomaly post Lisbon'. The Review recommended that more should be done to ensure that Article 33 TEU is implemented in such a way that EUSRs are an intrinsic part of the EEAS (EEAS Review 2013: 4-5).

The obligation to cooperate with the Member States in Article 221(2) TFEU is repeated and complemented by an obligation to share information in Article 5(9) EEAS Decisions, according to which they are to 'work in close cooperation and share information with the diplomatic services of the Member States' (Art 5(9) EEAS Decision). Although the reciprocal obligation to share information provided for in the initial draft does not appear in the final text of the Decision, the logic of the principle of sincere cooperation (Article 4(3) TEU) indicates that this cannot be only a one-way street (Wouters et al. 2013: 18-19), an issue also discussed by Hanses in chapter X.

The EEAS Review also notes that Article $5(10)^{4}$ indicates a potential future role for EU delegations in providing consular protection to EU citizens in third countries if the necessary expertise and resources were to be transferred from Member States (EEAS Review 2013: 12; Wouters et al. 2013: 76-77 and Wessel and Van Vooren 2013). Fernandes sets out the parameters and dilemmas involved in chapter $\mathrm{Y}$. Whether a transfer of consular 
responsibility is likely to occur in the foreseeable future, is of course a moot point. Some Member States, and the UK in particular, are not at all keen on the idea. In its 2013 Competence Review on Foreign Policy, the UK Government dryly noted that some evidence suggested 'that smaller Member States had an expansionist vision for the EEAS because it offers a global reach they cannot achieve by themselves. Over time they would like to see it take on a consular role. [...] The UK believes that consular protection should remain firmly the responsibility of Member States' (HM Government 2013: 91, para 6.14 and House of Lords European Union Committee 2013: 24-25, paras 60-63).).

\section{Constitutional Consequences}

\subsection{Competence Division between the EU and its Member States}

One of the more significant novelties introduced by the Lisbon Treaty is Title I of Part One of the FEU Treaty entitled 'Categories and Areas of Union Competence' (De Baere 2008: 6771). Three of these categories listed in Article 2 TFEU are most relevant for the Union's external relations and hence for the EEAS: exclusive competences (Art 2(1) TFEU), shared competences (Art 2(2) TFEU), and the competence to define and implement a CFSP, including the progressive framing of a CSDP (Art 2(4) TFEU).

The main principles regarding when the Union is exclusively competent have now been laid down in Article 3 TFEU, the first paragraph of which lists the five explicitly attributed or a priori exclusive competences of the Union. This category is rather small. It comprises the customs union, ie the original core of the Community, the establishing of the competition rules necessary for the functioning of the internal market, monetary policy for the Member States whose currency is the euro, the conservation of marine biological resources under the common fisheries policy and the common commercial policy ('CCP'). Given that they have important external relations aspects, the external dimensions of these policies belong to the exclusive competence of the Union. In addition, the second paragraph of Article 3 TFEU provides for the Union to have exclusive competence 'for the conclusion of an international agreement when its conclusion is provided for in a legislative act of the Union or is necessary to enable the Union to exercise its internal competence, or in so far as its conclusion may affect common rules or alter their scope' (Art 3(2) TFEU). While it attempts to codify the case-law of the Court of Justice of the EU (CJEU) on exclusive competences, the criteria listed in Article 3(2) TFEU appear to be neither entirely clear nor sufficiently nuanced and hence in need of further judicial clarification. The CJEU's existing case-law on the nature of EU external competences will therefore need to be taken into account (De Baere and Koutrakos 2012: 255-257). ${ }^{5}$

The exclusive or non-exclusive nature of an external competence also has a direct impact on the functioning of the EEAS within the EU's external action machinery. Where the EU has an exclusive competence and the Commission is in charge of the corresponding external action (the CCP would be the paradigmatic example), the Commission apparently prefers to act with no or minimal coordination with the EEAS. In particular, it has been reported that the Commission is reluctant to let Heads of Delegations (not infrequently 
Member State diplomats) take part in trade negotiations, which are undertaken by DG Trade, with the Delegations relegated to a reporting role (Wouters et al. 2013: 50-51 and 68 and House of Lords European Union Committee 2013: 42-43, paras 122-128).

The extent to which the establishment of the EEAS might affect the division of competences between the EU and its Member States was clearly an issue that caused some concern among the drafters of the Lisbon Treaty. That much is clear from declarations 13 and 14. By way of the former, the Intergovernmental Conference underlined

that the provisions in the Treaty on European Union covering the Common Foreign and Security Policy, including the creation of the office of High Representative of the Union for Foreign Affairs and Security Policy and the establishment of an External Action Service, do not affect the responsibilities of the Member States, as they currently exist, for the formulation and conduct of their foreign policy nor of their national representation in third countries and international organisations. ${ }^{6}$

If that (or indeed the Treaties themselves) were not clear enough, the IGC repeated the sentiment in Declaration 14, which provides that in addition to the specific rules and procedures referred to in Article 24, para 1 TEU,

the Conference underlines that the provisions covering the Common Foreign and Security Policy including in relation to the High Representative of the Union for Foreign Affairs and Security Policy and the External Action Service will not affect the existing legal basis, responsibilities, and powers of each Member State in relation to the formulation and conduct of its foreign policy, its national diplomatic service, relations with third countries and participation in international organisations, including a Member State's membership of the Security Council of the United Nations'. ${ }^{7}$

That concern is clearly reflected, for example, in the report of the UK House of Lords European Union Committee on the EEAS, which takes the view that the EEAS should not 'seek to project its own foreign policy. The Common Foreign and Security Policy should remain under the control of the Member States' (House of Lords European Union Committee 2013: 10, para 14).

This arguably makes the fact that the drafters only mentioned the bare minimum with respect to the EEAS in Article 27 TEU all the more surprising (Blockmans and Hillion 2013: 12). Instead of annexing two declarations on how the EEAS should not affect the vertical division of competences, the Member States could have simply circumscribed the functions of the EEAS more clearly in the Treaty. Be that as it may, the two declarations foreboded a general reluctance on the part of the Member States to use the post Lisbon institutional framework for external relations and a concomitant attempt to renationalise foreign policy. In turn, this forms at least part of the explanation why the EEAS has not led to a general increase in coherence and effectiveness of EU external action (Wouters et al. 2013: 30-31). The Member States' apprehension regarding the impact of the EEAS on their own external relations competences may, however, also be - at least to a certain extent - why the drafters of the Lisbon Treaty decided to provide the EEAS with a legal basis within the CFSP. Given that 
the CFSP is a sui generis type of competence outside the area of simple shared competences, there is some debate on whether it does fall under the general 'pre-emption' rule on shared competences in Article 2(2) TFEU, pursuant to which the Member States are to exercise their competence to the extent that the Union has not exercised its competence or has decided to cease exercising its competence (Hillion and Wessel 2008). The consequences for the choice of legal basis for the horizontal division of competences are examined below.

What then is the impact of the explicit confirmation of the Union's international legal personality as inserted in Article 47 TEU by the Lisbon Treaty (Wessel 2000, 2008)? The starting point of the Convention on the future of Europe's Working Group on Legal Personality was that the Union already possessed legal personality (European Convention WG III 2002). Indeed, international agreements had already been concluded in the name of the EU with third countries and international organizations. This might be said to indicate the will of at least part of the 'international legal community' to regard the EU as a legal person. The earliest example of such an agreement was Council Decision 2001/352/CFSP concerning the conclusion of the Agreement between the European Union and the Federal Republic of Yugoslavia (FRY) on the activities of the European Union Monitoring Mission (EUMM). ${ }^{8}$ The explicit confirmation of the EU's legal personality in the Lisbon Treaty hence did not change anything of substance. It neither altered the division of competences between the Union and the Member States nor between the ordinary EU external relations and the CFSP (European Convention WG III 2002: para 20). The fact that the EU is an international legal person is therefore merely the response of international law to what the International Court of Justice has referred to as 'the requirements of international life', 9 as influenced by the nature and functions of the EU. The explicit affirmation of the Union's legal personality by the Treaty of Lisbon has, however, had positive consequences for the overall transparency of the Union's constitutional system, both towards its citizens and towards 'the wider world'. Despite this, some Member States (and the UK in particular) have reportedly grown wary of the Union's use of its explicitly confirmed legal personality, fearing that it may lead to 'competence creep' (Wessel and Van Vooren 2013: 4). It is in that regard helpful to emphasise that it 'is important to bear in mind that in itself the attribution of personality to an entity means nothing' (Lauterpacht 1976: 403-413).

$\mathrm{Be}$ that as it may, given the EU's international legal personality, the Head of Delegation has the power to represent the Union in the country where the delegation is accredited, in particular for the conclusion of contracts, and as a party to legal proceedings (Art 5(8) EEAS Decision), though it is unclear whether he or she would also have the capacity to initial international agreements on behalf of the Union. At any rate, Article 218 TFEU would have to be complied with (Blockmans and Hillion 2013: 52). Art. 218 TFEU provides for a procedure for the conclusion of agreements between the Union and third countries or international organisations. Pursuant to these procedural rules, the Commission submits recommendations to the Council if an international agreement needs to be negotiated, unless the ordinary external relations aspects form only a minor part of an agreement that relates principally to the CFSP, in which case the High Representative submits these recommendations (Art. 218(3) TFEU). If it deems the negotiation of the agreement in question to be opportune, the Council adopts a decision authorising the opening of negotiations and, depending on the subject of the agreement envisaged, nominating the Union 
negotiator or the head of the Union's negotiating team (Art. 218(4) TFEU). Thus, Art. 218 TFEU spells out who is to submit recommendations under what circumstances, but does not explicitly determine who is to be the negotiator. While under the first subparagraph of Art. 300(1) EC, the Commission was to "conduct these negotiations", Art. 218(3) TFEU appears to give the Council a choice. ${ }^{10}$

It must be emphasised, however, that these rules govern only the representation of the Union and not of the Member States. Representation of member States falls outside the scope of the Treaties and remains governed by each county's own constitutional arrangements, in accordance with Art. 5(2) TEU. Thus, the Member States remain free to choose who will represent them internationally. They may request the rotating Presidency of the Council to represent them or the Commission, but they may equally opt to represent themselves. In other words, in case of mixed external action, two sets of rules apply: the rules in the Treaties as regards the Union, and the several constitutional rules of the Member States as regards their own international representation. While this may obviously lead to confusion, one should remember that the choice between the two options is limited by the principle of sincere cooperation (Art. 4(3) TEU), which applies even when the Member States are exercising their own competences. ${ }^{11}$ It obliges the Union and the Member States to cooperate loyally and is therefore of crucial importance in allowing the Union's system of international representation to operate in a more or less coherent manner.

Nevertheless, differences of opinion between the EU and the Member States on how the EU should be represented in multilateral settings have persisted. The UK's blocking of statements within the UN and the OSCE provided an example of how sensitive the precise division of competences between the Union and the Member States with respect to external representation had become (Wouters et al. 2013: 80; Wessel and Van Vooren 2013). The UK takes a restrictive view of the extent of EU delegations' right to deliver EU statements, because it believes that, in the absence of clarity over EU representation in international organisations, there is a risk that the Commission or the EEAS assumes that, 'having represented the Member States on an issue, it has gained unfettered competence to act'. As noted above, the UK is concerned that external representation may eventually lead to 'competence creep' (HM Government 2013: 40-41, para 3.35-3.37). In October 2011, COREPER eventually agreed on an arrangement on EU statements in multilateral settings (Council of the EU 2011), which according to the EEAS Review 'has provided greater guidance on the respective role of the EEAS, the rotating Presidency and Member States', while nevertheless noting that 'residual legal uncertainties in this area continue' (EEAS Review 2013: 11). However, the arrangement arguably espouses too rigid an interpretation of the concept of 'international unity' by requiring that each statement made in multilateral organizations traces who is competent for what, and ensuring that the internal division of competences is reflected externally on the statement's cover page and in the body of the text (Wessel and Van Vooren 2013: 5). As an illustration, it has been reported that in 2012, over half the EU statements at the UN were delivered 'on behalf of the EU and its Member States', while numerous others were delivered 'on behalf of the Member States of the EU' (Wouters et al. 2013: 80), a formula that appears to reduce the EU to a mere Member State coordination mechanism or a form of permanent diplomatic conference. 
A specific link with Member State competence will often be found in order to justify their participation in the conclusion of the agreement. And this usually implies a substantial role for the Presidency of the Council. The ensuing mixed agreement has to be ratified by both the Union and the member States individually. This requires the normal Art. 218 TFEU procedure and, in a clear majority of the cases, includes the formal involvement of the European Parliament (Art 218(6) TFEU). It also implies every single Member State must act according to its own constitutional procedures, most often including scrutiny and approval by Member State parliaments. This is the case, notwithstanding the fact that agreements that cover both issues falling within the exclusive competence of the Union and issues falling within shared competence may be concluded as pure EU agreements. In its Competence Review, the UK notes that the Commission and the EEAS 'have expressed their preference for such agreements to be EU-only', adding that the 'UK's practice is that Member States should also be party to such agreements when they cover areas of shared competence that the EU has not previously exercised, so that they constitute "mixed agreements" with both the EU and the Members States being parties' (HM Government 2013: 26, para 2.39).

\subsection{The Horizontal Division of Competences within the EU}

As chapter X outlines, the office of the High Representative constitutes one of the most significant constitutional innovations brought about by the Lisbon Treaty. With its entry into force, the High Representative replaced both the former High Representative for the CFSP and the Commissioner for external relations (Art. 18 TEU) (as the Union Minister for Foreign Affairs under the Constitution was originally intended to do). ${ }^{12}$ In conducting the Union's CFSP, presiding over the Foreign Affairs Council, and acting as one of the Vice-Presidents of the Commission (Art. 18(2)-(4) TEU), the High Representative forms a bridge between the CFSP and the other elements of the Union's external relations. The aim is to ensure greater coherence between the various elements of EU external action (European Convention WG VII 2002: 19). In EU constitutional law, based as it still is on the fundamental distinction between TFEU policies (the former first pillar) on the one hand, and the CFSP on the other, the office of the High Representative is not only a feat of constitutional innovation, but to an extent a curious anomaly in the current constitutional framework of the Union. There is a swathe of foreseen and unforeseen consequences, two of which are now highlighted.

First, the so-called 'triple-hatting' is widely believed to be excellent in theory, but rather fraught in practice. As the EEAS Review puts it: 'experience has clearly shown that this concentration of responsibilities in a single post generates a huge and relentless workload for one person' (EEAS Review 2013: 13). The issue is complicated in that the different hats correspond to different procedures, and the limited mandate and competences of the EEAS simply do not mirror the triple-hatting of the office of the High Representative. A system of deputisation has therefore been proposed (Wouters et al. 2013: 31-33). The EEAS Review suggests two alternative arrangements for the creation of deputies: formalisation of the current arrangements for other EU representatives (minister of the rotating presidency, Commissioners with geographical responsibilities, senior EEAS officials or EUSRs) or creation of a new formal deputy High Representative position. The former is achievable within the current Treaty framework, while the latter would likely involve amendment of the 
Treaties. In either option, the question of who should represent the High Representative in the European Parliament needs to be addressed. The EEAS Review proposes to extend the practice of the Foreign Affairs Committee to allow senior EEAS officials, Heads of Delegation and EUSRs to take the floor (EEAS Review 2013: 13). When she is unable to appear before Parliament, the High Representative currently tends to send either a minister or a commissioner to replace her. Yet, it is clear that, should a commissioner be appointed as permanent deputy to the High Representative, this would raise sensitivities about the status of Member States (House of Lords European Union Committee 2013: 12, para 21).

Second, Article 27 TEU sets out the tasks of the High Representative in the CFSP and at the same time functions as the legal basis for the EEAS, but it is situated in Chapter 2 'Specific Provisions on the Common Foreign and Security Policy' of Title V of the EU Treaty, rather than, say, in Chapter 1 'General Provisions on the Union's External Action'. In other words, the legal basis for the establishment of the EEAS is to be found in the CFSP. This implies that it must abide by Article $40 \mathrm{TEU}$, pursuant to which the implementation of the CFSP must not affect 'the application of the procedures and the extent of the powers of the institutions laid down by the Treaties for the exercise of the Union competences referred to in Articles 3 to 6 of the Treaty on the Functioning of the European Union', in other words, what used to be the first pillar. Reference is made to Article 40 TEU in Article 4(3)(a), third indent EEAS Decision with respect to the crisis management and planning directorate, the civilian planning and conduct capability, the European Union Military Staff and the European Union Situation Centre, placed under the direct authority and responsibility of the High Representative, and which are to assist her in conducting the Union's CFSP in accordance with the provisions of the Treaty 'while respecting, in accordance with Article 40 TEU, the other competences of the Union'. No other reference to Article 40 TEU appears in the decision, which is in any case not necessary for it to remain applicable. Under the pre-Lisbon ex Article 47 TEU, this would imply that if a CFSP measure might conceivably have been adopted on the basis of a first pillar legal basis, it would be annulled if its validity were to be challenged before the ECJ. Only if a measure were very clearly mainly CFSP and only very incidentally first pillar would it have been allowed to stand (Hillion and Wessel 2009). ${ }^{13}$

The position post Lisbon is less clear. Article 40 TEU now prohibits the CFSP and the TFEU competences from affecting each other. Would the EEAS Decision run the risk of accusation of affecting TFEU competences if its legality were challenged? There are clearly a number of provisions in the decision that do not cover simply the CFSP, such as Article 9 on 'External action instruments and programming' (Blockmans and Hillion 2013: 12 and 75-84). This should not come as a surprise, as the entire idea of the High Representative and the EEAS was to provide a bridge between first and second pillar external relations precisely in order to remedy to some extent the original sin of overall EU external relations. Be that as it may, the fact that the EEAS Decision was the result of a carefully negotiated compromise between the Council, the Commission, and the Member States, would seem to indicate that a legality challenge on the basis of Article 40 TEU appears unlikely. At any rate, the potential 'affectation' in Article 40 TEU probably only applies to legally binding decisions. This leaves ample scope for the EEAS to coordinate in a more informal way or on the basis of soft law measures (Blockmans and Hillion 2013: 13-14). 


\section{Conclusion}

The functioning of the EEAS depends not only on political factors related to the political will of the Member States or turf battles between the Institutions, but also on the legal competences the new body enjoys on the basis of the EU Treaties and secondary legislation. In analysing the current EU legal provisions with a view to establishing their impact on the functioning of the EEAS this chapter has assessed the legal aspects of the institutional organization of the EEAS and the Union delegations as well as the complex 'sui generis' division of competences between the EU institutions and the Member States in the area of foreign and security policy. With the entry into force of the Lisbon Treaty, the EU formulated clear global ambitions. Yet, the 2013 Review of the EEAS confirmed a number of shortcomings and dilemmas in the institutional set-up of this new body, which many observers, and not least officials of the EU, had pointed to from the outset (Piris 2010).

The succession of the European Community by the European Union changed the nature of the EU itself. The Lisbon Treaty confirmed the EU's legal personality and this makes it more difficult to use the term 'European Union' as a label for the collective nature of the Member States. Whereas the main purpose of the EEAS is to allow the EU to improve the organisation of its external relations and to pursue the aim of speaking with one voice, many legal provisions have been phrased in ways that take account of the fact that the EU is not a federal state and that Member States continue to play a (sometimes autonomous) role in international relations (Eckes and Wessel 2014). As also indicated in the chapter by Wouters and Duquet, the Union struggles with the fact that its non-state nature makes it difficult to play along on the basis of international rules and principles that were developed for states. The effectiveness of new diplomatic functions of the European Union will therefore depend on the acceptance by third states. At the same time, internal EU and Member State hesitations often block effective and coherent external action, and a revision of some of the EEAS rules seems to be required so as to take the special nature of CFSP into account, and this simultaneously offers a chance to repair some of the current shortcomings in the practical functioning of the Service.

\section{References}

Allott, P. (1999), 'The Concept of European Union' in A Dashwood and A Ward (eds) (Oxford and Portland, OR: Hart Publishing, 2000) 2 The Cambridge Yearbook of European Legal Studies 199937 and 46.

Bátora, J. (2013), “The Mitrailleuse Effect”: The EEAS as an Interstitial Organization and the Dynamics of Innovation in Diplomacy, Journal of Common Market Studies, 2013, Volume 51, Issue 4, pp. 598-613.

Blockmans, S. and Hillion, C. (2013) (eds), EEAS 2.0: A Legal commentary on Council Decision 2010/427/EU establishing the organisation and functioning of the European External Action Service (Brussels: CLEER Working Papers 2013/1)

Cappelletti, M., Seccombe, M., and Weiler, J.H.H. (1986) (eds), Integration Through Law. 
Europe and the American Federal Experience (Berlin: Walter de Gruyter, 1986).

Council of the European Union (2011), 'EU Statements in multilateral organisations: General Arrangements'. 15901/11. 24 October 2011.

De Baere, G. (2008), Constitutional Principles of EU External Relations (Oxford: OUP, 2008).

De Baere, G. (2012), 'European Integration and the Rule of Law in Foreign Policy' in

Dickson, J. and Eleftheriadis, P. (eds), Philosophical Foundations of European Union Law (Oxford: OUP, 2012) 354-383.

De Baere, G. and Koutrakos, P. (2012), 'The interactions between the legislature and the judiciary in EU external relations' in Syrpis, P. (ed.), The Judiciary, the Legislature and the EU Internal Market (Cambridge: Cambridge University Press, 2012) 243-273.

Eckes, C. and Wessel, R.A. (2014), 'The European Union from an International Perspective: Sovereignty, Statehood, and Special Treatment', in T. Tridimas and R. Schütze (Eds.), The Oxford Principles of European Union Law - Volume 1: The European Union Legal Order (Oxford: Oxford University Press, 2014 - forthcoming)

Erkelens, L. and Blockmans, S. (2012), 'Setting up the European External Action Service: an act of institutional balance', European Constitutional Law Review, Vol. 8 (2012), pp. 246-279.

European Commission Secretariat General (2012), Working Arrangements Between Commission Services and the European External Action Service (EEAS) in Relation to External Relations Issues, SEC(2012)48, 13 January 2012.

European Convention WG III (2002), Final Report of Working Group III on Legal Personality, CONV305/02, Brussels, 2002.

European Convention WG VII (2002), Final Report of the Working Group VII on External Action, CONV 459/02, Brussels 16 December 2002,

European External Action Service (2013), EEAS Review, 2013.

Hillion, C. and Wessel, R.A. (2008), 'Restraining External Competences of EU Member States under CFSP', in M. Cremona and B. De Witte (Eds.), EU Foreign Relations Law: Constitutional Fundamentals, Oxford: Hart Publishing, pp. 79-121.

Hillion, C. and Wessel, R.A. (2009), 'Competence Distribution in EU External Relations after ECOWAS: Clarification or Continued Fuzziness?' 46 Common Market Law Review, 551-586.

HM Government (2013), Review of the Balance of Competences between the United Kingdom and the European Union Foreign Policy.

House of Lords European Union Committee (2013), The EU's External Action Service, $11^{\text {th }}$ Report of Session 2012-13, HL Paper 147.

Lauterpacht, E. (1976), 'The Development of the Law of International Organizations by the Decisions of International Tribunals' in (1976) 152 Recueil des Cours 377-478.

Piris, Jean-Claude (2010) The Lisbon Treaty: A Legal and Political Analysis, Cambridge.

Van Vooren, B. (2011) 'A legal-institutional perspective on the European External

Action Service', Common Market Law Review 48(2): 475-502.

Wessel, R.A. (2000) 'Revisiting the international legal status of the EU', European Foreign Affairs Review 5: 507-37.

Wessel, R.A. (2008) 'The European Union as a party to international agreements: shared 
competences, mixed responsibilities', in A. Dashwood and M. Maresceau (eds), Law and Practice of EU External Relations - Salient Features of a Changing Landscape, Cambridge: Cambridge University Press, pp. 145-80.

Wessel, R.A. and Van Vooren, B. (2013), 'The EEAS's diplomatic dreams and the reality of European and international law', Journal of European Public Policy, 1-18.

Wessel, R.A. (2013), 'Can the European Union Replace its Member States in International Affairs? An International Law Perspective', in I. Govaere, E. Lannon, P. Van Elsuwege, S. Adam (Eds.), The European Union in the World: Essays in Honour of Marc Maresceau, Leiden/Boston: Martinus Nijhoff Publishers, pp. 129-147.

Wessel, R.A. (2014), 'The Legal Dimension of European Foreign Policy', in A..K. Aarstad, E. Drieskens, K.E. Jørgensen, K. Laatikainen and B. Tonra (Eds.), Handbook of European Foreign Policy, London: Sage.

Wouters, J., De Baere, G., Van Vooren, B., Raube, K., Odermatt, J., Ramopoulos, T., Van den Sanden, T., Tanghe, Y. (2013), The Organisation and Functioning of the European External Action Service: Achievements, Challenges and Opportunities, 93 pp. Brussels: European Parliament, Directorate-General for External Policies of the Union, Directorate B, Policy Department.

Wouters, J. and Duquet, S. (2012), 'The EU and International Diplomatic Law: New Horizons?' (2012) 7 Hague Journal of Diplomacy, 31-49.

\footnotetext{
${ }^{1}$ For the appropriateness of the usage of the term 'constitutional law' in relation to the EU, see e.g. A. Rosas and

${ }^{2}$ On what that may mean: Blockmans and Hillion 2013: 14-18.

${ }^{3}$ But see Recital 8 in the preamble to the EEAS Decision: 'For matters relating to its staff, the EEAS should be treated as an institution within the meaning of the Staff Regulations and the [Conditions of Employment of Other Servants of those Communities ('CEOS')]'.

${ }^{4}$ The text of the EEAS Review mistakenly refers to Article 5(9).

${ }^{5}$ In that sense also: Opinion of AG Kokott in Case C-137/12 Commission v Council EU:C:2013:675, points 111113.

${ }^{6}$ [2012] OJ C326/345 (emphasis added).

${ }^{7}$ [2012] OJ C326/345 (emphasis added).

${ }^{8}$ [2001] OJ L125/1.

${ }^{9}$ Reparation for Injuries suffered in the Service of the United Nations [1949] ICJ Reports 174, 178.

${ }^{10}$ See, however, Art. 207(3) TFEU and Art. 219(3) TFEU.

${ }^{11}$ See, for example, Case C-246/07 Commission v Sweden ('PFOS') EU:C:2010:203 [2010] ECR I-3317.

${ }^{12}$ Compare Art I-28 of the Treaty establishing a Constitution for Europe [2004] OJ C310/1.

${ }^{13}$ See Case C-91/05 Commission v Council EU:C:2008:288 [2008] ECR I-3651.
} 